\title{
Present and forecasted xeric climatic limits of beech and sessile oak distribution at low altitudes in Central Europe
}

\author{
Bálint Czúcz • László Gálhidy • Csaba Mátyás
}

Received: 30 October 2009 / Accepted: 6 July 2010 /Published online: 22 February 2011

(C) INRA and Springer Science+Business Media B.V. 2011

\begin{abstract}
- Introduction Xeric (trailing) forest range limits are particularly vulnerable to impacts of predicted climate change. Regional modelling studies contribute to the identification of potential local climatic threats and may support appropriate management strategies.

- Methods We carried out bioclimatic distribution modelling of two climate-dependent, dominant tree species, beech and sessile oak, to determine the most influential climatic variables limiting their distributions and to predict their climate-induced range shifts over the twenty-first century in the forest-steppe biome transition zone of Hungary. To exclude confounding effects of edaphic conditions, only data of zonal sites were evaluated.

- Results For both species, temperature and precipitation conditions in late spring and summer appear as principal variables determining the distribution, with beech particularly affected by summer drought. Projections from the applied fine-scale analysis and modelling results indicate
\end{abstract}

Handling Editor: Gilbert Aussenac

B. Czúcz

Hungarian Academy of Sciences, Institute of Ecology and Botany,

Alkotmány u. 2-4,

Vácrátót 2163, Hungary

L. Gálhidy

WWF-Hungary,

Álmos vezér útja 69/A,

1141, Budapest, Hungary

C. Mátyás $(\square)$

Institute of Environment and Earth Sciences, University of West

Hungary, Faculty of Forestry,

PO Box 132, 9401, Sopron, Hungary

e-mail: cm@emk.nyme.hu that climate change may lead to drastic reduction in macroclimatically suitable sites for both forest types.

- Conclusion Regarding the stands in zonal position, 56$99 \%$ of present-day beech forests and $82-100 \%$ of sessile oak forests might be outside their present bioclimatic niche by 2050 . Phenotypic plasticity, longevity, endurance of non-zonal stands and prudent human support may brighten these dire predictions. Nevertheless, an urgent adjustment of forest management and conservation strategies seems inevitable.

Keywords Climate change $\cdot$ Trailing edge $\cdot$ Range retraction · Aridity Ensemble modelling

\section{Introduction}

Climate projections of the Intergovernmental Panel on Climate Change (IPCC) forecast a general increase of seasonal temperatures in the present century across the temperate zone, aggravated by decreasing amounts of summer rainfall in certain regions at lower latitudes (Christensen et al. 2007). These changes imply serious ecological consequences, especially in biome transition zones (Fischlin et al. 2007). Due to their economic importance, as well as their major contribution to supporting, regulating and cultural ecosystem services, predicted changes and shifts in temperate forest ecosystems receive wide public attention. It's no surprise that dominant forest tree species are frequently modelled in bioclimatic impact studies (e.g., Sykes et al. 1996; Iverson, Prasad 2001; Rehfeldt et al. 2003; Ohlemüller et al. 2006). However, most studies focus on continental-scale effects of climate change, using low resolution climatic and species distribution data. 
More detailed regional studies focussing on specific endangered regions are also needed (Benito Garzón et al. 2008). Such regional studies have already been prepared for several European regions, including the Swiss Alps (Bolliger et al. 2000), the British Isles (Berry et al. 2002) and the Iberian Peninsula (Benito Garzón et al. 2008).

In this study, we aim to (1) identify the limiting macroclimatic factors and to (2) predict the future boundaries of beech (Fagus sylvatica L.) and sessile oak (Quercus petraea (Mattuschka) Liebl.) forests in a region highly vulnerable to climatic extremes. Both tree species form extensive zonal forests throughout Central Europe and reach their low altitude/low latitude, xeric (Mátyás et al. 2009) distributional limits within the forest-steppe biome transition zone of Hungary. The rise of temperature, and especially summer rainfall deficits expected for the twentyfirst century, may strongly affect both species. Nevertheless, regarding the potential future distribution of these important forest tree species along their xeric boundaries in Central Europe, there has been no detailed regional analysis before. Experimental studies and field survey data suggest a strong decline in beech regeneration (Czajkowski et al. 2005; Penuelas et al. 2007; Lenoir et al. 2009) and increased mortality rates following prolonged droughts (Berki et al. 2009). Mass mortality and range retraction are potential consequences, which have been already sporadically observed in field survey studies (Jump et al. 2009; Allen et al. 2010; Mátyás et al. 2009). With the study, we intend to assist in assessing overall risks, locating potentially affected regions and supporting the formulation of appropriate measures and strategies.

Beech and sessile oak forests of Hungary are to a large extent "trailing edge" populations (Hampe and Petit 2005), which should be preferably modelled using specific modelling strategies (Thuiller et al. 2008). Most modelling studies do not differentiate between leading and trailing edges and rely on assumptions and techniques which are intrinsically more appropriate for "leading edge" situations. Being aware of these challenges, we compiled a statistical methodology customized to yield inference on influential variables and providing robust and reliable predictions for climate-dependent populations near their xeric limits. We laid special emphasis on three features in the course of the modelling process: (1) screening of the occurrence data in order to limit modelling to plausible zonal (i.e. macroclimatically determined) occurrences, (2) avoiding pitfalls of statistical pseudoreplication caused by spatial autocorrelation (a problem to which regional distribution modelling studies are particularly prone; Dormann 2007) and (3) simultaneous use of several initial and boundary conditions in an ensemble modelling framework (Araújo et al. 2005; Araújo and New 2007; Beaumont et al. 2007).

\section{Materials and methods}

\subsection{Study area}

Hungary lies in the centre of the Carpathian Basin; the larger half of the country is flat and below $200 \mathrm{~m}$ a.s.l. elevation, and less than $1 \%$ rises above $800 \mathrm{~m}$. The temperate continental climate is characterized by relatively frequent summer droughts, and there is an aridity gradient across the country towards the central part of the Great Hungarian Plain, where the closed forest belt gives way to open woodlands (forest steppe).

From the forest steppe limit upward, in sequence of their moisture requirement, Turkey oak (Quercus cerris), sessile oak ( $Q$. petraea), hornbeam (Carpinus betulus) and European beech ( $F$. sylvatica) dominate the zonal forests as climate indicators. Out of the four, only European beech and sessile oak distributions were modelled, the other two play a lesser role in forest management.

\subsection{Forestry data}

Data of stands containing the two species were derived from the National Forest Inventory database of the State Forest Service. This annually updated database holds data of practically all forest stands within the country on an individual stand (i.e. compartment) basis. For the analysis, data of version 2002 were used. Non-zonal stands (e.g. on shallow soil, steep slope, etc.), or heavily disturbed (with significant proportion of alien tree species), as well as small, fragmentary stands $(<1$ ha) have been excluded. The

Table 1 List of the selected climatic variables and abbreviations

\begin{tabular}{ll}
\hline Climatic variable & Abbreviation \\
\hline Annual precipitation & $P \mathrm{a}$ \\
Summer half year precipitation (Apr-Sep) & $P \mathrm{~s}$ \\
Summer season precipitation (Jun-Aug) & $P_{\mathrm{s} 3}$ \\
May precipitation & $P_{05}$ \\
June precipitation & $P_{06}$ \\
July precipitation & $P_{07}$ \\
August precipitation & $P_{08}$ \\
Annual temperature & $T a$ \\
Mean temp. of summer half year (Apr-Sep) & $T s$ \\
Mean temp. of summer season (Jun-Aug) & $T \mathrm{~s} 3$ \\
Mean temp. of winter half year (Oct-Mar) & $T \mathrm{w}$ \\
Mean May temperature & $T_{05}$ \\
Mean June temperature & $T_{06}$ \\
Mean July temperature & $T_{07}$ \\
Mean August temperature & $T_{08}$ \\
Ellenberg's Climate Quotient & $\mathrm{EQ}$ \\
Führer's Forest Aridity Index & $\mathrm{FAI}$ \\
\hline
\end{tabular}


remaining stands were regarded as representative for climate-dependent occurrences under moderate human influence. It has to be noted here that the term "zonal stand" is used in the whole paper in the strictest sense, defined as occurrence primarily determined by macroclimate; therefore, instead of "extrazonal" or "azonal", the term "non-zonal" is used for sites not fulfilling this requirement.

For the spatial determination of compartment locations, the inventory grid system of the Forest Service was utilized $(\sim 1.5 \times 1.9 \mathrm{~km}$ grid cells covering the entire country). The geometrical centre of the grid cell served as a reference point to estimate local climate parameters from digital climate surfaces. This was considered sufficiently precise for the aims of the study.
In order to set the focus unilaterally onto the xeric margin of distribution, two specific aspects were considered for presence/absence interpretation. (1) For each compartment, we decided whether the given species plays a (co)dominant role (proportion $\geq 20 \%$ ) in the stand. (2) As interspecific competition is governed at the xeric limits by available water resources, a "humidity requirement ranking" (Führer and Járó 1992: beech $>$ hornbeam $>$ sessile oak $>$ Turkey oak) between these species was applied. We considered a site suitable (which is humid enough) for the species, if it was (co-) dominated by the species in question or by another major species with higher humidity needs. Thus, for sessile oak, zonal forest stands dominated or co-dominated by hornbeam or beech were also considered as "presence" irrespective of the proportion of sessile oak in the compartment. Due to its
Table 2 Parameters of each of the ten bootstrapped decision tree models on the xeric limits of beech and sessile oakdominated zonal forest stands calculated without ("basic") or with ("extended") aridity indices (see details in text)
Tree depth the maximum number of nested levels (partitions); tree width the number of terminal nodes ("leaves"); $\kappa$ maximum of Cohen's kappa; ROC/ $A U C$ area under the receiver operating characteristics curve of the model projections on the evaluation data set; root split the splitting variable and the corresponding split value selected for the first partition

${ }^{\mathbf{a}}$ The marked models are shown in detail in Fig. 1

\begin{tabular}{|c|c|c|c|c|c|}
\hline \multicolumn{5}{|c|}{ a) Beech (Fagus sylvatica) } & \multirow{2}{*}{$\begin{array}{l}\text { Basic } \\
\text { Root split }\end{array}$} \\
\hline & Tree depth & Tree width & $\kappa$ & ROC/AUC & \\
\hline 1 & 3 & 5 & 0.35 & 0.77 & $P_{05}(76.8 \mathrm{~mm})$ \\
\hline 2 & 6 & 8 & 0.39 & 0.83 & $T_{05}\left(13.4^{\circ} \mathrm{C}\right)$ \\
\hline 3 & 5 & 7 & 0.38 & 0.82 & $T_{05}\left(13.7^{\circ} \mathrm{C}\right)$ \\
\hline 4 & 5 & 8 & 0.40 & 0.82 & $T_{05}\left(13.7^{\circ} \mathrm{C}\right)$ \\
\hline $5^{a}$ & 4 & 7 & 0.34 & 0.79 & $T_{05}\left(14.0^{\circ} \mathrm{C}\right)$ \\
\hline 6 & 4 & 7 & 0.35 & 0.80 & $T_{05}\left(14.1^{\circ} \mathrm{C}\right)$ \\
\hline 7 & 5 & 9 & 0.43 & 0.82 & $T_{05}\left(13.7^{\circ} \mathrm{C}\right)$ \\
\hline 8 & 4 & 7 & 0.36 & 0.81 & $T_{05}\left(13.6^{\circ} \mathrm{C}\right)$ \\
\hline 9 & 6 & 9 & 0.45 & 0.84 & $T_{05}\left(13.7^{\circ} \mathrm{C}\right)$ \\
\hline 10 & 5 & 8 & 0.38 & 0.82 & $T_{05}\left(13.6^{\circ} \mathrm{C}\right)$ \\
\hline \multicolumn{5}{|c|}{ b) Beech (Fagus sylvatica) } & Extended \\
\hline 1 & 3 & 6 & 0.41 & 0.81 & EQ (26.2) \\
\hline $2^{a}$ & 3 & 5 & 0.40 & 0.83 & EQ (26.1) \\
\hline 3 & 5 & 6 & 0.41 & 0.81 & EQ (26.4) \\
\hline 4 & 4 & 6 & 0.47 & 0.83 & EQ (25.8) \\
\hline 5 & 4 & 7 & 0.36 & 0.80 & $T_{05}\left(14^{\circ} \mathrm{C}\right)$ \\
\hline 6 & 5 & 6 & 0.41 & 0.80 & EQ (26.2) \\
\hline 7 & 4 & 7 & 0.41 & 0.80 & $T_{05}\left(13.7^{\circ} \mathrm{C}\right)$ \\
\hline 8 & 2 & 4 & 0.47 & 0.84 & EQ (26.0) \\
\hline 9 & 4 & 6 & 0.45 & 0.83 & $T_{05}\left(13.7^{\circ} \mathrm{C}\right)$ \\
\hline 10 & 3 & 5 & 0.43 & 0.83 & EQ (26.9) \\
\hline \multicolumn{5}{|c|}{ c) Sessile oak (Quercus petraea) } & Basic and extended \\
\hline 1 & 5 & $8 / 7$ & 0.37 & 0.76 & $P_{05}(60.2 \mathrm{~mm})$ \\
\hline 2 & 4 & 7 & 0.39 & 0.76 & $P_{05}(60.8 \mathrm{~mm})$ \\
\hline 3 & 6 & 10 & 0.35 & 0.74 & $P_{05}(58.8 \mathrm{~mm})$ \\
\hline $4^{a}$ & 4 & 6 & 0.37 & 0.75 & $P_{05}(58.8 \mathrm{~mm})$ \\
\hline 5 & 4 & 8 & 0.40 & 0.76 & $P_{05}(58.9 \mathrm{~mm})$ \\
\hline 6 & 4 & $9 / 8$ & 0.35 & 0.71 & $T_{08}\left(19.4^{\circ} \mathrm{C}\right)$ \\
\hline 7 & 4 & 9 & 0.31 & 0.74 & $P_{05}(65.6 \mathrm{~mm})$ \\
\hline 8 & 3 & 7 & 0.33 & 0.73 & $T_{08}\left(19.2^{\circ} \mathrm{C}\right)$ \\
\hline 9 & 4 & 7 & 0.32 & 0.72 & $P_{05}(61.6 \mathrm{~mm})$ \\
\hline 10 & 3 & $7 / 6$ & 0.33 & 0.73 & $T_{08}\left(19.5^{\circ} \mathrm{C}\right)$ \\
\hline
\end{tabular}



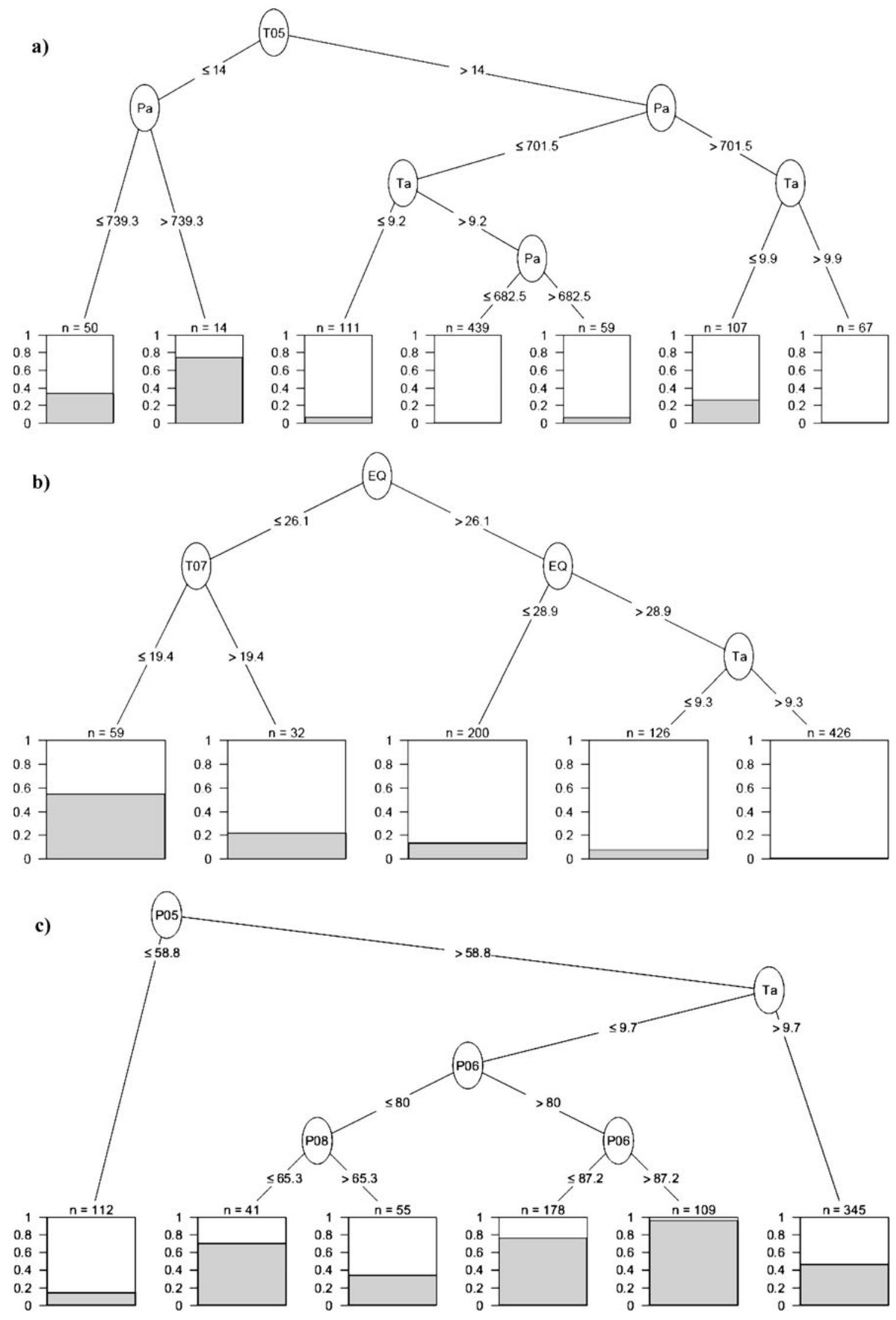
Fig. 1 Examples of the decision tree-based bioclimatic models for xeric limits of the zonal forest stands dominated by a beech (basic predictors only), $\mathbf{b}$ beech (with EQ included) and $\mathbf{c}$ sessile oak. In the terminal nodes, bar diagrams visualize the probability of being above the aridity limit, with the partition of objects from the training data set among the leaf nodes on the top of the diagram boxes ( $n$ ) See Table 1 for variable names

distribution in the country, this interpretation was unnecessary for beech.

Consecutively, the screened zonal, semi-natural compartments have been grouped by grid cells, defining the response variable as the percentage of presence in the respective grid cell. Thus, the data set was reduced from the originally selected 31,113 stands to 5,925 "observations", each one belonging to a different cell.

\subsection{Climatic data}

Interpolated climate surfaces of the decades 1961-1990 have been provided by the Hungarian Meteorological Service. We used 14 basic climatic variables listed in Table 1. In addition, we also considered two simple aridity indices routinely used in Hungarian forest research:

1 Ellenberg's climate quotient (EQ; Ellenberg 1988), defined as the mean temperature of the warmest month (July, $\left.T_{07}\right)$ divided by annual precipitation $\left(P_{a n n}\right)$ :

$$
\mathrm{EQ}=1,000 \cdot T_{07} \cdot P_{\mathrm{ann}}^{-1}
$$

2 Simplified forest aridity index (FAI; Führer and Járó 1992):

$$
\mathrm{FAI}=100 \cdot T_{07-08} \cdot\left(P_{05-07}+P_{05-08}\right)^{-1},
$$

where $P_{05-07}$ represents the precipitation sum of the rainiest months of May to July, $T_{07-08}$ and $P_{07-08}$ are the mean temperatures and the precipitation sums of the so-called critical months of July and August (thus, the precipitation value for the crucial month of July is weighted by a factor of 2 in the denominator).

Owing to the screening process, sites with soils with less than medium deep tilt or with other defects were omitted, so the introduction of a separate variable "water holding capacity of soil' was considered unnecessary. Elevation and aspect were considered indirectly through the use of digital climate surfaces.

For predicting future distributions, climatic projections of the Fourth Assessment Report (AR4) of the IPCC (Solomon et al. 2007) were applied. We used combinations of three emission scenarios and four general circulation models (GCMs), thus, representing both socioeconomic and climatic uncertainties in the outputs (see later Table 3 ).
Based on the available monthly means of the model runs, we calculated 30-year monthly averages for near-surface air temperature and total precipitation for the periods 2010 2040, 2035-2065 and 2070-2100 (referred to as projections for 2025, 2050 and 2085, respectively). Applied climate surfaces have been adjusted according to projected changes.

\subsection{Handling spatial autocorrelation}

Spatial autocorrelation is a common problem for inferences based on statistical models. These rely on the assumption of independence of the residuals. Even though our modelling approach, conditional inference-based regression trees (see later), is immune to most problems of statistical inference (see Zuur et al. 2009 for a comprehensive list, Hothorn et al. 2006b), it is still sensitive to spatial autocorrelation, which inflates the risk of type I error in the permutation tests used for variable selection and as a stopping rule. Significant autocorrelation can accordingly result in oversized trees, which are difficult to interpret and may contain irrelevant or misleading relationships. To avoid problems of autocorrelation, we fitted a conditional inference-based regression tree on the entire data set and calculated Mantel correlograms (Legendre and Fortin 1989) of the residuals using Euclidean distances for both the ecological (relative frequency of species by grid cell) and the geographical variables. The calculations were performed with the ecodist add-on package (Goslee and Dean 2007) in the $R$ statistical environment ( $R$ Development Core Team 2007). The results of the Mantel test (not shown) indicate that autocorrelation of the residuals disappears at a distance of $\sim 8 \mathrm{~km}$. Nevertheless, as high sampling distance results in reduced sample sizes, we chose an average sampling distance of $6.8 \mathrm{~km}$ (four grid cells) as a sensible compromise (providing 700 samples).

\subsection{Statistical analysis}

We fitted several regression tree models to subsets of the forestry data in a bootstrap-like framework, using different calibration and evaluation data sets each time. To this end, we randomly selected two disjunct subsets of the initial data pool in the following way: (1) we divided the forestry grid into groups of $4 \times 4$ adjacent grid cells (according to the autocorrelation threshold estimated above), and (2) from each cell group, we randomly placed one grid cell into each (calibration and evaluation) subset. We repeated this sampling process ten times, evaluating each model and constructing projections with them for all scenarios and time horizons in an ensemble framework (Araújo and New 2007).

As the main modelling tool, we used conditional inference-based regression trees (Hothorn et al. 2006a). 
The response variable was the relative frequency of presence within the grid cells of the calibration data set. To test the effectiveness of climate/aridity indices, the decision tree models were calculated both with ("extended models") and without ("basic models") their inclusion among the covariates. The computations were performed by the ctree algorithm in the party add-on package (Hothorn et al. 2006a) in the $R$ statistical environment. The conditional inference-based algorithm of Hothorn et al. (2006a); 2006b) is a significant recent improvement of classification and regression tree algorithms (e.g. Breiman et al. 1984), implementing unbiased variable selection based on explicit permutation test and a statistically sound stopping rule, thus, completely eliminating the need for post-induction pruning.

The accuracy of the models was estimated by two different statistical measures using the evaluation data set. First, the threshold independent skill measure of the area under the curve (AUC) statistic of the receiver operating characteristic (ROC) curve (Fielding and Bell 1997; Manel et al. 2001) was computed. Secondly, we calculated the K statistics, using a threshold-search algorithm optimized for the value of this statistic (Monserud and Leemans 1992). To transform probability values into binary projections of climatic suitability, we used a threshold maximising the sum of sensitivity and specificity of the predictions over the evaluation data set (Jiménez-Valverde and Lobo 2007; Kramer et al. 2010).

Future projections were calculated only for the "extended" models. Having an ensemble of GCM scenarios (boundary conditions) and bootstrapped models (initial conditions), it was possible to prepare a high number of projections of the future potential distribution of the tree species $(6 \times 10$ projections for each time horizon). To obtain consensus forecasts, we took unweighed averages of the individual projections (committee averaging: Araújo and New 2007). To get a simple overview of the reliability of the consensus projection, we also calculated a map of standard deviations for each forest type and time horizon, thus, representing the uncertainty of projections.

\section{Results}

Evaluation statistics of the fitted models are shown in Table 2 for both "basic" and "extended" models for all ten replications. It is only in the case of beech that the inclusion of the climatic indices changed the results considerably; the models for sessile oak were hardly affected. Fortunately, despite of the limited overlap between different bootstrapping rounds, there is a fairly high level of coherence among the resulting decision tree models. This, together with the ROC AUC statistics, which are generally considered as fair between $0.7-0.8$ and good between $0.8-0.9$ (see e.g. Thuiller et al. 2003), suggests that the patterns observed are real, and the predictive power of the models is satisfactory for both tree species. Examples for the described cases are presented in Fig. 1.

The projected potential distributions of the two species are shown in Figs. 2 and 3. The results show that climate change may lead to drastic reduction in macroclimatically suitable sites for both beech and sessile oak forests. Applying the calculated thresholds to the probabilistic projections reveals that 56-99\% of present-day zonal beech forests and $82-100 \%$ of sessile oak forests might be outside their optimal bioclimatic niche by 2050. Potential area reduction is highest for scenario HadCM3-A2 and lowest for CSMK3-A2 (Table 3). However, CSMK3 scenarios are
Fig. 2 Actual distribution of beech-dominated zonal forest stands in Hungary (a), consensus projection maps for the probability of presence $(\mathbf{b}-\mathbf{e})$ and their uncertainty (f). Time horizons for the mean projections: 1975 (b), 2025 (c), 2050 (d), 2085 (e). The intensity of shading indicates the probability of the location to be above the xeric limit for stable zonal stands. Tile (f) demonstrates uncertainty by the standard deviation of the ensemble runs for the 2050 time horizon
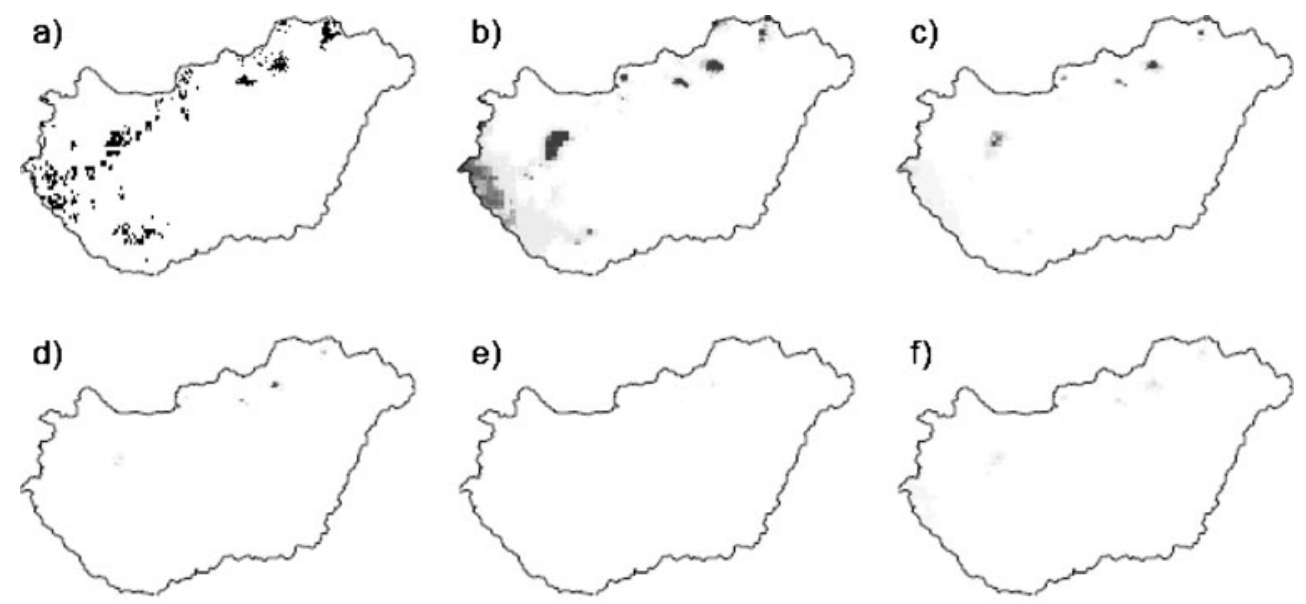

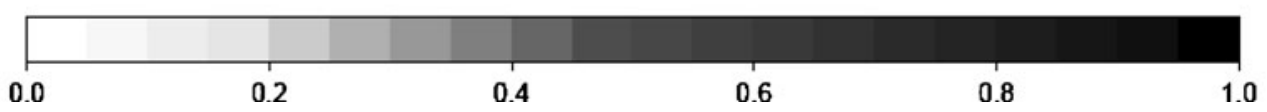


Fig. 3 Actual distribution of sessile oak-dominated zonal forest stands in Hungary (a), and consensus projection maps for the probability of presence $(\mathbf{b}-\mathbf{e})$ and their uncertainty (f). Time horizons for the mean projections: 1975 (b), 2025 (c), 2050 (d), 2085 (e). The intensity of shading indicates the probability of the location to be above the xeric limit for stable zonal stands of the forest type. Tile (f) demonstrates uncertainty by the standard deviation of the ensemble runs for the 2050 time horizon
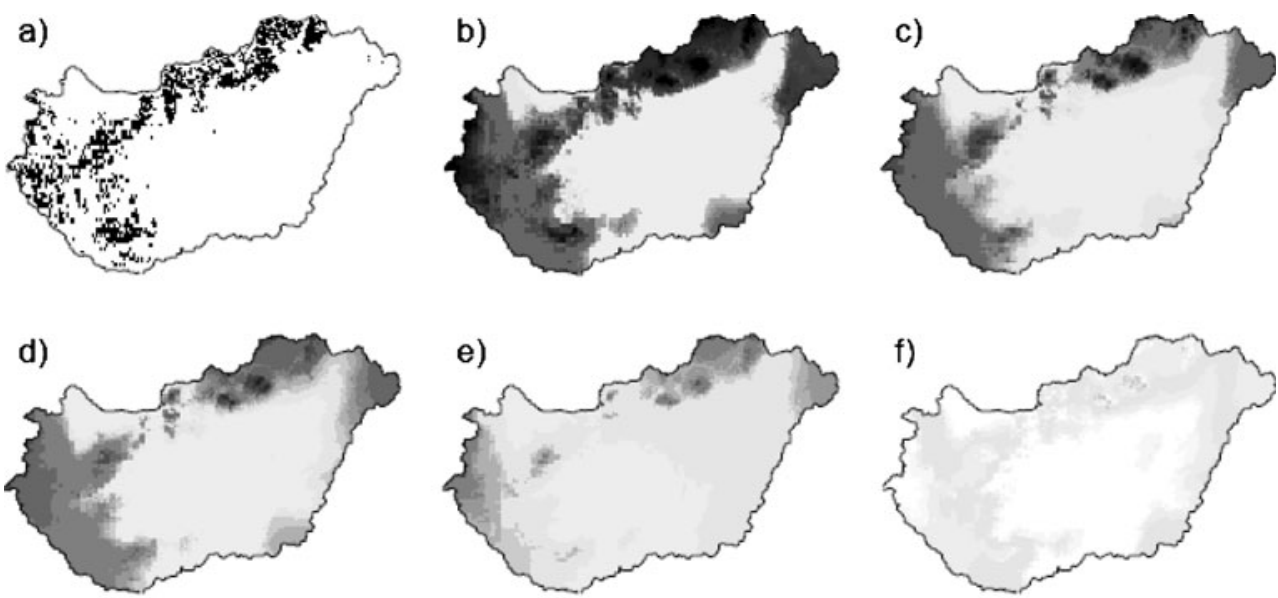

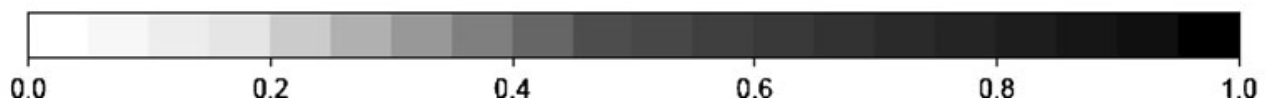

milder than all other scenarios, projecting less summer warming and no significant decrease in precipitation during either half year.

\section{Discussion}

In the case of beech, late spring (May) temperature appears to be the most influential predictor out of the basic set of climatic variables (Table 2a). In addition, subsequent splits show that annual precipitation also plays a significant role in the presence of beech near its xeric limit (see Fig. 1a for an example of such a tree). Grid cells with high late spring temperatures $\left(T_{05}>13.5-14^{\circ} \mathrm{C}\right)$ contain relatively few beech stands. Alternatively, cells with the highest probability of presence had relatively cool May temperatures $\left(T_{05}<14^{\circ} \mathrm{C}\right)$ and received a relatively high amount of rainfall $(>740 \mathrm{~mm})$ per year.

The inclusion of aridity indices resulted in a definite change. Whenever Ellenberg's climate quotient (EQ) was included among the predictor variables, it almost always appeared as the most distinguishing predictor (Table 2b, Fig. 1b). FAI, the other composite index, never occurred among the splitting variables. Apart from EQ, May temperature, annual temperature, and, less frequently, annual precipitation and July temperature values appeared in the bootstrapped decision tree models (the latter two are nevertheless included in EQ). Our results, underlining the importance of May-July water availability in the survival of beech, are coherent with results obtained from dendrochronological analyses (Dittmar et al. 2003; Lebourgeois et al. 2005; Di Filippo et al. 2007).

For sessile oak, the inclusion of aridity indices has hardly caused any change in the models. Minor differences are caused by the disappearance of marginally significant splits as Bonferroni-corrected significance levels change with the increasing number of predictors tested in lines 1 and 10 in Table $2 \mathrm{c}$ or the appearance of EQ in one of the branches in line 6 in Table 2c (not shown). It seems that in this case, neither EQ nor FAI is a better predictor than the primary climatic parameters. May precipitation is the climatic parameter with the highest potential to discriminate

Table 3 Expected changes of climatic conditions by 2050 and estimated area loss of zonal beech ( $\Delta$ beech) and sessile oak ( $\Delta$ sessile oak) forest stands in Hungary

\begin{tabular}{lccccrrr}
\hline & HADCM3 A2 & HADCM3 A1B & HADCM3 B1 & CNCM3 A2 & CSMK3 A2 & GFCM21 A2 \\
\hline$\Delta T \mathrm{~s}$ & +2.9 & +3.3 & +2.6 & +2.4 & +1.8 & +2.1 \\
$\Delta T \mathrm{w}$ & +2.3 & +2.6 & +2.3 & +2.1 & +1.5 & +1.6 \\
$\Delta P \mathrm{~s}$ & $-13.4 \%$ & $-10.9 \%$ & $-12.4 \%$ & $-9.6 \%$ & $+0.4 \%$ & $-11.4 \%$ & $+3.3 \%$ \\
$\Delta P \mathrm{~W}$ & $+7.0 \%$ & $+9.4 \%$ & $+3.5 \%$ & $97-99 \%$ & $97-99 \%$ & $56-96 \%$ & $92-99 \%$ \\
$\Delta$ beech & $97-99 \%$ & $94-99 \%$ & $90-100 \%$ & $95-100 \%$ & $82-96 \%$ & $85-100 \%$ \\
$\Delta$ sessile oak & $96-100 \%$ & $97-100 \%$ & &
\end{tabular}

Projected changes in summer/winter half year temperature $\left(\Delta T \mathrm{~s} / \Delta T \mathrm{w},{ }^{\circ} \mathrm{C}\right)$ and precipitation $(\Delta P \mathrm{~S} / \Delta P \mathrm{~W}$, percents $)$ are shown for Hungary for six IPCC AR4 climatic scenarios (Solomon et al. 2007) for the period 2035-2065 
between presence and absence of sessile oak stands. August temperature, annual temperature and June precipitation seem to be further important splitting variables (Fig. 1c). The importance of May and June precipitation is in agreement with the investigations of Lebourgeois et al. (2004) in Western France, where they found only a limited effect of temperature. Late spring and early summer precipitation were also identified as main climatic variables governing growth of holm oak (Quercus ilex) in dry woodlands of Spain (Gea-Izquierdo et al. 2009).

Terminal nodes with zero (or close to zero) probability for sessile oak presence are remarkably absent from all tree models. This can be attributed to the scarcity of seminatural zonal forests in the lowlands and foothills caused by a combination of ecological and historical factors.

Table 3 reveals surprisingly high levels of range reduction in the case of both species. To interpret these figures correctly, one must remember that only zonal forest stands were included into the analysis. Accordingly, occurrences considered non-zonal may harbour populations for a long time into the future.

The fundamental role of summer precipitation in determining future aridity is further illustrated by the projections for the different climatic scenarios (Table 3). The outlying CSMK3 scenario points to the consequences of high uncertainty of precipitation trends. Hungary lies very close to the climatic division line separating areas of increasing (N. Europe) and decreasing (S. Europe) precipitation both in summer and winter (Christensen et al. 2007). Close to the xeric limits, relatively slight deviations in the climate pattern may seriously affect summer precipitationdependent beech.

The more drought tolerant sessile oak (Führer and Járó 1992; Raftoyannis and Radoglou 2002) is also projected to suffer large-scale losses, although the probabilistic maps of Fig. 3 reveal a considerable level of uncertainty. Uncertainty is higher for sessile oak than for beech. Beech forests are more climate-determined (as can be seen also from the AUC values of Table 2), but uncertainty is rather caused by the above mentioned incertitude in climate predictions. On the other hand, uncertainties for sessile oak arise primarily from the data used for modelling: occurring generally at lower elevations, their actual distribution contains more human-induced "noise", indicated by the probabilistic projections (Fig. 3).

Due to the constraints of the analysed data, a realistic comparison of the obtained results with other published ones was possible only for beech. Table 4 shows published climate data for low latitude/low altitude limits of beech partially derived from climate envelops. For obvious reasons, the majority of studies used readily available annual means, in two cases only a single factor (Bolte et al. 2007). The study of Fang and Lechowicz (2006) analysed a larger number of climate factors and indices, among them Ellenberg's index. We explain the relatively wide scatter of data on climatic limits partly with the large size and the climatic diversity of the investigated regions of distribution, and with the lack of focus on zonal occurrences. The limited availability of precise distribution and climate data certainly contributed to this. Despite of the differences in volume and quality of the evaluated dataset, the closeness of the estimated EQ limit of Fang and Lechowicz (2006) to ours is surprising, although an accidental similarity cannot be excluded.

\section{Conclusions}

In this paper, we present an approach to analyse climate factors determining the drought-prone, xeric limits of distribution in a human-dominated environment, based on extensive data screening and a novel combination of applied modelling methods. Late spring and summer water balance conditions appear to primarily determine the fate of the species. The power of Ellenberg's climate quotient as a predictor corroborates the sensitivity of beech to summer drought whereas sessile oak seems to be responsive primarily to late spring-early summer precipitation and late summer temperatures. Projections based on IPCC scenarios indicate a dramatic reduction of the macroclimatically suitable areas for both beech and sessile oak in the following decades. Field observations near the xeric

Table 4 Comparison of results of the present analysis with literature data on xeric limits of beech occurrence

\begin{tabular}{llll}
\hline Source & Temperature limit $\left({ }^{\circ} \mathrm{C}\right)$ & Precipitation limit (mm) & EQ index limit $\left({ }^{\circ} \mathrm{C} / \mathrm{mm}\right)$ \\
\hline Fang and Lechowicz 2006 & Ann. mean, 13.5; warmest month, 23.0 & Ann. mean, 900 & 29.0 \\
Kölling 2007, cool-dry limit & Ann. mean, 9.5 & Ann. mean, 500 & - \\
Kölling 2007, warm-humid limit & Ann. mean, 13.5 & Ann. mean, 850 & - \\
Goetz in: Bolte et al. 2007 & - & Ann. mean, 500 & - \\
Hoffman in: Bolte et al. 2007 & July mean, <19.0 & - & - \\
Present analysis & Ann. mean, 9.3 & Ann. mean, 680 & 28.9 \\
\hline
\end{tabular}


distributional limits of these species already confirm symptoms of this process (Jump et al. 2006; Berki et al. 2009; Penuelas et al. 2007).

In addition to the uncertainties discussed in the previous chapter, it has to be noted that statistical models using climate data do not reckon with specific biological features of forest tree populations, such as their persistence due to adaptability, longevity and intermittent regeneration. The authors believe that the suggested future distributions represent rather pessimistic scenarios which may be moderated not only by the mentioned characteristics but also by the existence of non-zonal refugia and the effect of prudent human support (e.g. artificial regeneration and other silvicultural measures). This calls for relevant, welldesigned field studies and further development of prediction methods and modelling (Mátyás 2010).

However, challenging the analysis of climate impacts at the xeric limits certainly needs more attention. Lowland regions are particularly threatened, as potential vegetation shifts may affect large tracts of land (Jump et al. 2009). Large-scale shifts of vegetation cover may have far-reaching consequences on land use and ecosystem services, including exchange processes between ecosystems and the atmosphere. Considering the rapid shrinking of suitable bioclimatic space and the increasing selection pressure of abiotic and biotic stressors at the xeric limits, the results underline the importance of adaptive strategies both for management and conservation of forest resources (Millar et al. 2007; Koskela et al. 2007; Mátyás 2007). The strengthening of long-term efforts to maintain forest-related socioeconomic and ecosystem services is therefore indispensable.

Acknowledgements The support of the National Research and Development Programs (NKFP 6/047/2005, TÁMOP 4.2.2) of the EU Network of Excellence "EVOLTREE" and of the Hungarian Academy of Science (Supported Research Unit on Production Biology) as well as the detailed and founded critics of three anonymous reviewers is gratefully acknowledged.

\section{References}

Allen CD, Macalady AK, Chenchouni H, Bachelet D, McDowell N, Vennetier M, Kitzberger T, Rigling A, Breshears DD, Hogg EH, Gonzales P, Fensham R, Zhang Z, Castro J, Demidova N, Lim JH, Allard G, Running SW, Semerci A, Cobb N (2010) A global overview of drought and heat-induced tree mortality reveals emerging climate change risks for forests. For Ecol Manage 259:660-684

Araújo MB, Whittaker RJ, Ladle RJ, Erhard M (2005) Reducing uncertainty in projections of extinction risk from climate change. Glob Ecol Biogeogr 14:529-538

Araújo MB, New M (2007) Ensemble forecasting of species distributions. Trends Ecol Evol 22:42-47

Beaumont LJ, Pitman AJ, Poulsen M, Hughes L (2007) Where will species go? Incorporating new advances in climate modelling into projections of species distributions. Glob Change Biol 13:1368-1385

Berki I, Rasztovits E, Móricz N, Mátyás Cs (2009) Determination of the drought tolerance limit of beech forests and forecasting their future distribution in Hungary. Cereal Res Commun 37:613-616

Berry PM, Dawson TP, Harrison PA, Pearson RG (2002) Modelling potential impacts of climate change on the bioclimatic envelope of species in Britain and Ireland. Glob Ecol Biogeogr 11:453462

Benito Garzón M, De Sánchez Dios R, Sainz Ollero H (2008) Effects of climate change on the distribution of Iberian tree species. Appl Veg Sci 11:169-178

Bolliger J, Kienast F, Zimmermann NE (2000) Risks of global warming on montane and subalpine forests in Switzerland-a modeling study. Reg Environ Change 1:99-111

Bolte A, Czajkowski T, Kompa T (2007) The north-eastern distribution range of European beech-a review. Forestry 80 (4):413-429

Breiman L, Friedman J, Ohlsen R, Stone C (1984) Classification and regression trees. Chapman and Hall/CRC Press, New York

Christensen JH, Hewitson B, Busuioc A, Chen A, Gao X, Held I, Jones R, Kolli RK, Kwon W-T, Laprise R, Magaña Rueda V, Mearns L, Menéndez CG, Räisänen J, Rinke A, Sarr A, Whetton P, Regional Climate Projections et al (2007) In: Solomon S, Qin $\mathrm{D}$, Manning M (eds) Climate change: the physical science basis. Contribution of working group I to the Fourth Assessment Report of the Intergovernmental Panel on Climate Change. Cambridge University Press, Cambridge, pp 747-845

Czajkowski T, Kuhling M, Bolte A (2005) Einfluss der Sommertrockenheit im Jahre 2003 auf das Wachstum von Naturverjüngungen der Buche (Fagus sylvatica L.) im nordöstlichen Mitteleuropa. Allg Forst- u J-Ztg 176:133-143

Di Filippo A, Biondi F, Cufar K et al (2007) Bioclimatology of beech (Fagus sylvatica L.) in the Eastern Alps: spatial and altitudinal climatic signals identified through a tree-ring network. J Biogeogr 34:1873-1892

Dittmar C, Zech W, Elling W (2003) Growth variations of common beech (Fagus sylvatica L.) under different climatic and environmental conditions in Europe-a dendroecological study. Forest Ecol Manag 173:63-78

Dormann CF (2007) Promising the future? Global change projections of species distributions. Basic Appl Ecol 8:387-397

Ellenberg H (1988) Vegetation ecology of Central Europe, 4th edn. Cambridge University Press, Cambridge

Fang J, Lechovicz MJ (2006) Climatic limits for the present distribution of beech (Fagus L.) species in the world. J Biogeogr 33:1804-1819

Fielding AH, Bell JF (1997) A review of methods for the assessment of prediction errors in conservation presence/absence models. Environ Conserv 24:38-49

Fischlin A, Midgley GF, Price JT, Leemans R, Gopal B, Turley C, Rounsevell MDA, Dube OP, Tarazona J, Velichko AA (2007) Ecosystems, their properties, goods, and services. In: Parry ML, Canziani OF, Palutikof JP et al (eds) Climate change: impacts adaptation and vulnerability. Contribution of Working Group II to the Fourth Assessment Report of the Intergovernmental Panel on Climate Change. Cambridge University Press, Cambridge, pp 211-272

Führer E, Járó Z (1992) Auswirkungen der Klimaaenderung auf die Waldbestaende Ungarns. Allg Forstztg 9:25-27

Gea-Izquierdo G, Martín-Benito D, Cherubini P, Canellas I (2009) Climate-growth variability in Quercus ilex L west Iberian open woodlands of different stand density. Ann For Sci 66:802

Goslee S.C., Dean L., The ecodist package for dissimilarity-based analysis of ecological data, J. Stat. Software 22 (2007) issue 7 
Hampe A, Petit RJ (2005) Conserving biodiversity under climate change: the rear edge matters. Ecol Lett 8:461-467

Hothorn T., Hornik K. Zeileis A. (2006a) Party: a laboratory for recursive partitioning. R package version 0.9-0. http://cran.r-project.org/doc/ packages/party.pdf

Hothorn T, Hornik K, Zeileis A (2006) Unbiased recursive partitioning: a conditional inference framework. J Comput Graph Stat 15:651-674

Iverson LR, Prasad A (2001) Potential changes in tree species richness and forest community types following climate change. Ecosyst 4:186-199

Jiménez-Valverde A, Lobo JM (2007) Threshold criteria for conversion of probability of species presence to either-or presenceabsence. Acta Oecol 31:361-369

Jump AS, Hunt JM, Penuelas J (2006) Rapid climate change-related growth decline at the southern range edge of Fagus sylvatica. Glob Change Biol 12:2163-2174

Jump A, Mátyás Cs, Penuelas J (2009) The paradox of altitude for latitude comparisons in species range retractions (Review). Trends Ecol Evol 24(12):694-700. doi:10.1016/j.tree.2009.06.007

Kölling C (2007) Klimahüllen von 27 Waldbaumarten. AFZ Wald 23:1242-1244

Koskela J, Teissier BA, du Cros E (eds) (2007) Climate change and forest genetic diversity: implications for sustainable forest management in Europe. Biodiversity International, Rome

Kramer K, Degen B, Buschboom J, Hickler T, Thuiller W, Sykes M, de Winter W (2010) Modelling exploration of the future of European beech (Fagus sylvatica L.) under climate change-range, abundance, genetic diversity and adaptive response. Forest Ecol Manag 259(11):2213-2222. doi:10.1016/j.foreco.2009.12.023

Lebourgeois F, Cousseau G, Ducos Y (2004) Climate-tree-growth relationships of a Quercus petraea Mill. stand in the Forest of Bercé ("Futaie des Clos", Sarthe, France). Ann For Sci 61:361372

Lebourgeois F, Bréda N, Ulrich E, Granier A (2005) Climate-treegrowth relationships of European beech (Fagus sylvatica L.) in the French Permanent Plot Network (RENECOFOR). Trees Struct Funct 19:385-401

Legendre P, Fortin MJ (1989) Spatial pattern and ecological analysis. Vegetatio 80(2):107-138

Lenoir J, Gégout JC, Pierrat JC, Bontemps JD, Dhote JF (2009) Differences between tree species seedling and adult altitudinal distribution in mountain forests during the recent warm period (1986-2006). Ecography 32:765-777

Manel S, Williams HC, Ormerod SJ (2001) Evaluating presenceabsence models in ecology: the need to account for prevalence. Ecology 38:921-931

Mátyás C (2007) What do field trials tell about the future use of forest reproductive material. In: Koskela J, Buck A, du Teissier Cros E (eds) Climate change and forest genetic diversity: implications for sustainable forest management in Europe. Biodiversity International, Rome, pp 53-69

Mátyás C, Vendramin GG, Fady B (2009) Forests at the limit: evolutionary-genetic consequences of environmental changes at the receding (xeric) edge of distribution. Ann For Sci 66:800-803

Mátyás C (2010) Forecasts needed for retreating forests (Opinion). Nature 464:1271

Millar CI, Stephenson NL, Stephens SL (2007) Climate change and forests of the future: managing in the face of uncertainty. Ecol Appl 17:2145-2151

Monserud RA, Leemans R (1992) Comparing global vegetation maps with the kappa statistic. Ecol Model 62:275-293

Ohlemüller R, Gritti ES, Sykes MT, Thomas CD (2006) Quantifying components of risk for European woody species under climate change. Glob Change Biol 12:1788-1799

Penuelas J, Ogaya R, Boada M, Jump AS (2007) Migration, invasion and decline: changes in recruitment and forest structure in a warming-linked shift of European beech forest in Catalonia (NE Spain). Ecography 30:829-837

R Development Core Team (2007) R: a language and environment for statistical computing. R Foundation for Statistical Computing, Vienna, http://www.R-project.org

Raftoyannis Y, Radoglou K (2002) Physiological responses of beech and sessile oak in a natural mixed stand during a dry summer. Ann Bot 89:723-730

Rehfeldt GE, Tchebakova NM, Milyutin LI, Parfenova EI, Wykoff WR, Kouzmina NA (2003) Assessing population responses to climate in Pinus silvestris and Larix spp. of Eurasia with climate transfer models. Euras J For Res 6:83-98

Solomon S., Qin D., Manning M. et al. (2007) (eds) Climate change: the physical science basis. Contribution of Working Group I to the 4th Assessment Report of the IPCC. Cambridge University Press, Cambridge

Sykes MT, Prentice IC, Cramer W (1996) A bioclimatic model for the potential distributions of north European tree species under present and future climates. J Biogeogr 23:203-233

Thuiller W, Vayreda J, Pino J, Sabate S, Lavorel S, Gracia C (2003) Large-scale environmental correlates of forest tree distributions in Catalonia (NE Spain). Glob Ecol Biogeogr 12(4):313-325

Thuiller W, Albert C, Araújo MB, Berry PM, Cabeza M, Guisan A, Hickler T, Midgley GF, Paterson J, Schurr FM, Sykes MT, Zimmermann NE (2008) Predicting global change impacts on plant species' distributions: future challenges. Perspect Plant Ecol Evol Systemat 9:137-152

Zuur AF, Ieno EN, Elphick CS (2009) A protocol for data exploration to avoid common statistical problems. Methods in Ecology and Evolution 1:3-14 